\title{
MULTIVARIATE ANALYSIS OF SUGAR YIELD COMPONENTS IN SUGARCANE
}

\author{
(Received: 27.9.2011)
}

\author{
By \\ H. M. Al-Sayed, H. S. A. Fateh*and W. M. Fares*

\begin{abstract}
Sugar Crops Research Institute, Agricultural Research Center, Giza, and * Central Laboratory of
\end{abstract} \\ Design \& Statistical Analysis Research, Agricultural Research Center, Giza.
}

\begin{abstract}
Two field experiments were conducted at Mallawy Research Station, Menia Governorate, during the two successive seasons of 2009/2010 and 2010/2011 to evaluate some statistical methods that used for estimating the relative contribution of sugar yield components in sugarcane crop. The present work included nine treatments which were the combination between three treatments of growth promoters (Agrispon, Stimulate and control) and three genotypes of sugarcane namely: G.T. 54-9, G. 84-47 and Phil- 8013. Five statistical procedures were used to study the relationship between sugar yield and its components using the data over the two seasons. The used methods of analysis were simple correlation coefficient, path analysis, full model regression, stepwise multiple linear regression and factor analysis. Highly significant and positive correlation coefficients were detected between sugar yield and each of number of internodes/stalk, number of millable stalks $/ \mathrm{m}^{2}$, total soluble solids $\%$ and sucrose $\%$. The results of path analysis revealed that the number of millable stalks $/ \mathrm{m}^{2}$ was the most important trait with the highest direct and indirect effects on sugar yield followed by sucrose $\%$ and stalk weight. The same three traits were also responsible for the most sugar yield variability using full model regression and stepwise multiple linear regression with goodness of fit of the two models. Factor analysis grouped the studied eight traits as sugar yield components into three main factors accounting for $85.3 \%$ of the total variability in the dependence structure. Factor I was responsible for 34.89 of the total variation and included stalk weight, stalk diameter and number of millable stalks $/ \mathrm{m}^{2}$. Factor II contained total soluble solids $\%$ and sucrose $\%$ and contributed to $28.17 \%$ of the total variation. Stalk length, number of internodes/stalk and reducing sugar \% were the components of the last factor and explained $22.25 \%$ of the total variation. Based on the previous results, it could be concluded that the high sugar yield of sugarcane crop would be obtained by selecting breeding materials that have heavy weight of stalk, large number of millable stalks $/ \mathrm{m}^{2}$ and high percent of sucrose.
\end{abstract}

Key words: factor analysis, path coefficient, Saccharum spp., stepwise regression.

\section{INTRODUCTION}

Sugarcane is still considered the major source of sugar supply in Egypt. So, it is necessary to increase its sugar yield to meet the continuous needs of an ever increasing population. Sugar yield is a complex quantitative characteristic that is the final expression and contributions of its components. Hence, determining the most important affecting factors to the total variability of sugar yield is a vital target to achieve a successfull breeding program. Great efforts have been made to develop proper models that can explain and predict the relationship between the sugar yield and its components and also the interrelationships among them. Choosing the appropriate model is a special challenge faced the- statisticians. Applying integrated analysis contained many statistical models may be other choice.

Five statistical techniques have been used in modeling sugar yield variability, including simple correlation, multiple regression analysis in full model and stepwise procedures, path analysis and factor analysis.

Breeding decisions based only on correlation coefficients may not always be effective since they provide only one-dimensional information neglecting important and complex interrelationships among plant traits (Kang, 1994). Path coefficient analysis separates the direct effect from the indirect effects through other related 
traits by partitioning the simple correlation coefficients (Dewey and Lu, 1959).

The study of casual relationship between sugar yield and its related characteristics using the two former techniques was applied by many investigators, such as Ahmed et al.(2010) who found a positive correlation between cane yield and each of the number of millable stalks $/ \mathrm{m}^{2}$, stalk length, number of internodes/stalk and single stalk weight. Also, they noted a negative association of cane yield with stalk diameter, juice pol and purity $\%$.

Tyagi and Lai (2007) reported that the weight of millable stalks was the most important component with the highest direct effect on sugarcane yield followed by stalk length, the number of millable stalks and stalk diameter.

On the other hand, El-Shafai and Ismail (2006) used full model regression and stepwise multiple linear regression techniques to study the relationship between sugar yield and its components in sugarcane. They reported that cane yield, sugar recovery $\%$ and stalk diameter were the main variables that significantly explain variability of sugar yield expressed as $\left(\mathrm{R}^{2}\right)$ of $63.41,36.11$ and $0.13 \%$, respectively.

Factor analysis is a type of multivariate analysis that can be used to reduce a large number of correlated variables to a small number of independent main factors. El-Geddawi et al. (1992) used factor analysis to determine the dependence structure of cane yield through some morphological and chemical traits. They pointed out that factor analysis divided the studied traits into four groups or factors accounted for $76.88 \%$ of the total variability in the dependence structure. The first factor contained the chemical characteristics that were most contributing to cane yield. These traits were richness $\%$, sucrose $\%$, brix $\%$ and purity $\%$.

The present investigation was aimed to assist the relationship between sugar yield and its components in sugarcane using five statistical procedures namely: simple correlation, path analysis, full model regression, stepwise multiple linear regression and factor analysis. The results may be helpful to plan appropriate selection strategies for improving sugarcane crop.

\section{MATERIALS AND METHODS}

Two field experiments were conducted at Mallawy Research Station, Menia Governorate, during the two successive seasons of 2009/2010 and $2010 / 2011$ to evaluate some statistical approaches used for estimating the relative contribution of sugar yield factors in sugarcane. Three treatments of growth promoters (Agrispon, Stimulate and without treatment as a control) were applied on three genotypes of sugarcane namely: G.T. 54-9, G. 84-47 and Phil 8013 to study the interrelationships among sugar yield factors under different degrees of variation.

The treatments were arranged in a split plot design and replicated three times. The treatments of growth promoters were devoted to the main plots while the sub plots were randomly assigned to sugarcane varieties. The sub plot area was 35 $\mathrm{m}^{2}$ including 5 rows, $7 \mathrm{~m}$ long and $100 \mathrm{~cm}$ between rows. Cultural practices were maintained at the recommended levels to satisfy the maximum cane yield and sugar yield.

At harvest, three guarded rows from each plot were harvested, topped and cleaned to estimate the following traits:

1- Stalk weight $(\mathrm{kg})$

2- Stalk length $(\mathrm{cm}) \quad 3$ - Stalk diameter $(\mathrm{cm})$

4-Number of internodes/stalk

5- Number of millable stalk $/ \mathrm{m}^{2}$

6- Total soluble solids \% or (Brix \% )

7- Sucrose \% 8- Reducing sugar \%

9- Sugar yield $($ ton/fed $)=$

cane yield (ton/fed) x sugar recovery $\%$.

\subsection{Statistical analysis}

Five statistical procedures differ in their mathematical concept, target and final output were separately evaluated to explore the relationship between sugar yield and its components in sugarcane. The used models were summarized as follows:

2.1.1. Simple correlation: a matrix of simple correlation coefficients between sugar yield and each of its components was computed as applied by Steel and Torrie (1980).

2.1.2. Path analysis: the methodology proposed by Dewey and Lu (1959) was used to partition the simple correlation coefficients of the previous step into direct and indirect effect.

2.1.3. Multiple linear regression: full model regression was estimated according to Draper and Smith (1981) using sugar yield as a resultant variable and its related characters as explanatory variables.

2.1.4. Stepwise multiple linear regression: this model was used according to Draper and smith (1981) to determine the variables that accounted for the majority of the total sugar yield variability.

To avoid the lack of fit of both Full model regression and Stepwise multiple linear regression 
as a result of multicollinearity phenomenon (the strong association among sugar yield components), the level of multicollinearity was estimated using a common measure namely: Variance Inflated Factor (VIF) as suggested by Hair et al. (1992). Large VIF values (above 10) reported high collinearity causing a rejected model (Hair et al., 1992).

2.1.5.Factor analysis: this statistical approach was applied according to Cattell (1965) to reduce a large number of correlated variables to a much smaller number of independent clusters of variables called factors. After the loading of the first factor was calculated, the process was repeated on the residuals matrix to find further factors. When the contribution of a factor to the total percentage of the trace was less than $10 \%$, the process was stopped. After extraction, the matrix of factor loadings was submitted to a varimax orthogonal rotation, as applied by Kaiser (1958). The purpose of rotation was to rebuilding the larger loadings in each factor and to suppress the minor loading coefficient so as to improve the opportunity of achieving meaningful biological interpretation of each factor.

\section{RESULTS AND DISCUSSION 3.1.Simple correlation matrix}

Correlation coefficients between all pairs of studied traits are shown in Table (1). The results revealed that there was a highly significant positive correlation between sugar yield and each of sucrose $\%(0.722 * *)$, total soluble solids \% $\left(0.621^{* *}\right)$ number of internodes/stalk $\left(0.436^{* *}\right)$, and number of millable stalks $/ \mathrm{m}^{2}\left(0.4^{* *}\right)$. Stalk length had only significant positive association with sugar yield recording $\mathrm{r}$ value of $0.332^{*}$. Accordingly, the breeder should exploit the previous characteristics to achieve high sugar yield of sugarcane. However, insignificant associations were observed between sugar yield and each of stalk length, stalk diameter and reducing sugar indicating that these traits may be independent in their genetic expression under the present study.

On the other hand, the sugar yield components exhibited important trends of associations among themselves. Negative and highly significant correlation was found between stalk weight and each of stalk length $\left(-0.467^{* *}\right)$ and number of millable stalks $/ \mathrm{m}^{2}\left(-0.803^{* *}\right)$. The correlation between stalk length and each of number of internodes/stalk, number of millable stalks $/ \mathrm{m}^{2}$, total soluble solids $\%$ and sucrose $\%$ was found to be positive and highly significant with $\mathrm{r}$ values being $0.669^{* *}, 0.600^{* *}, 0.425^{* *}$ and $0.402^{* *}$, respectively. Also, highly significant and negative correlation coefficient was observed between stalk diameter and number of millable stalks $/ \mathrm{m}^{2}$ with value of $-0.814^{* *}$. Positive and highly significant correlation was also detected between total soluble solids $\%$ and sucrose $\%\left(0.895^{* *}\right)$. The sugarcane breeder must take in account the interrelationships among the sugar yield components when planning the breeding program.

It is worthwhile to state that the large sample size $(n=54)$ of data may be a reason of the significance of some small values of correlation coefficients. The present results are similar to those reported by Tyagi and Lai (2007), Ahmed et al. (2010) and Iiyas and khan (2010).

\subsection{Path analysis}

Information obtained from simple correlation coefficient can be enlarged by partitioning it into direct and indirect effects for a given set of casual interrelationships. The matrix of direct and joint effects for the studied characters is shown in Table (2).

The maximum direct effects were obtained for number of millable stalks $/ \mathrm{m}^{2}(0.962)$, followed by sucrose \% (0.739) and stalk weight $(0.731)$. It is reported that the indirect effects of number of millable stalks $/ \mathrm{m}^{2}$ and sucrose \% were less important compared to their direct effects. The high positive direct effects of the number of millable stalks $/ \mathrm{m}^{2}$ and sucrose $\%$ in addition to their highly significant coefficients of correlation is an evidence that the direct selection through the two traits would be effective for improving sugar yield of sugarcane.

In contrast, although significant positive coefficients of correlation were recorded between sugar yield and each of stalk length, number of internodes/stalk and total soluble solids \%, their direct effects were negligible. This result may be attributed to that path analysis discarded the indirect effects from the simple correlation coefficient. The components of indirect effect were more important than the part of direct effect considering the traits of stalk length, stalk diameter and number of internodes/stalk. Their highest values of indirect effect on sugar yield were observed with the number of millable stalks $/ \mathrm{m}^{2}$ recording $0.577,-0.783$ and 0.397 , 
Table (1): Matrix of simple correlation coefficients among sugar yield and its components in sugarcane over 2009/2010 and 2010/2011 seasons.

\begin{tabular}{|c|c|c|c|c|c|c|c|c|c|}
\hline Traits & SW & SL & SD & NI & NMS & TSS \% & $\mathrm{S} \%$ & RS \% & SY \\
\hline Stalk weight (SW) & $\mathbf{1}$ & $-0.467 * *$ & $0.878 * *$ & -0.181 & $-0.803 * *$ & -0.056 & -0.013 & -0.036 & 0.088 \\
\hline Stalk length (SL) & & $\mathbf{1}$ & $-0.369 * *$ & $0.669 * *$ & $0.600 * *$ & $0.425 * *$ & $0.402 * *$ & 0.258 & $0.332 *$ \\
\hline Stalk diameter (SD) & & & 1 & -0.105 & $-0.814 * *$ & -0.074 & -0.021 & -0.142 & -0.037 \\
\hline No. internodes/stalk (NI) & & & & 1 & $0.413 * *$ & 0.220 & $0.322 *$ & $0.311 *$ & $0.436 * *$ \\
\hline No. millable stalks $/ \mathrm{m}^{2}$ (NMS) & & & & & $\mathbf{1}$ & 0.269 & 0.250 & 0.182 & $0.400 * *$ \\
\hline Total soluble solids (TSS \%) & & & & & & 1 & $0.895 * *$ & -0.129 & $0.621 * *$ \\
\hline Sucrose \% (S \%) & & & & & & & & -0.250 & $0.722 * *$ \\
\hline Reducing sugar \% (RS \%) & & & & & & & & 1 & 0.106 \\
\hline Sugar yield (SY) & & & & & & & & & 1 \\
\hline
\end{tabular}

Table (2): Path coefficients (direct and joint effects) of sugar yield and its related characters in sugarcane.

\begin{tabular}{|c|c|c|c|c|c|c|c|c||c|}
\hline Characters & SW & SL & SD & NI & NMS & TSS\% & S\% & RS\% & $\mathbf{r}_{\mathbf{x y}}$ \\
\hline SW & $\underline{\mathbf{0 . 7 3 1}}$ & 0.082 & 0.062 & -0.008 & -0.772 & 0.009 & -0.010 & -0.006 & 0.088 \\
SL & -0.341 & $\underline{\mathbf{- 0 . 1 7 5}}$ & -0.026 & 0.029 & 0.577 & -0.071 & 0.297 & 0.042 & $0.332 *$ \\
SD & 0.642 & 0.065 & $\underline{\mathbf{0 . 0 7 0}}$ & -0.005 & -0.783 & 0.012 & -0.016 & -0.023 & -0.037 \\
NI & -0.132 & -0.117 & -0.007 & $\underline{\mathbf{0 . 0 4 4}}$ & 0.397 & -0.037 & 0.238 & 0.050 & $0.436 * *$ \\
NMS & -0.587 & -0.105 & -0.057 & 0.018 & $\underline{\mathbf{0 . 9 6 2}}$ & -0.045 & 0.185 & 0.029 & $0.400 * *$ \\
TSS\% & -0.041 & -0.074 & -0.005 & 0.01 & 0.259 & $\underline{\mathbf{- 0 . 1 6 8}}$ & 0.661 & -0.021 & $0.621 * *$ \\
S\% & -0.010 & -0.070 & -0.001 & 0.014 & 0.240 & -0.150 & $\underline{\mathbf{0 . 7 3 9}}$ & -0.040 & $0.722 * *$ \\
$\mathbf{R S \%}$ & -0.026 & -0.045 & -0.01 & 0.014 & 0.175 & 0.022 & -0.185 & $\underline{\mathbf{0 . 1 6 2}}$ & 0.106 \\
\hline
\end{tabular}

Residual effect $=\mathbf{0 . 3 8 2}$

Note: $\mathrm{SW}=$ stalk weight, $\mathrm{SL}=$ stalk length, $\mathrm{SD}=$ stalk diameter, $\mathrm{NI}=$ number of internodes $/ \mathrm{stalk}$, NMS= number of millable stalks $/ \mathrm{m}^{2}$, $\mathrm{TSS} \%=$ total soluble solids $\%, \mathrm{~S} \%=$ sucrose $\%$ and $\mathrm{RS} \%=$ reducing sugar $\%$.

- The direct effects occupied the diagonal cells (bold and underline).

respectively. Considering the trait of total soluble solids $\%$, the important part of its joint effects was that via sucrose $\%$ listing 0.661 .

In fact, the efficiency of path analysis is clear in the present study. For example, the association between stalk weight and sugar yield was not significantly different from zero (0.088) considering only simple correlation coefficient. When the indirect effects are separated from simple correlation coefficient by path analysis, however, the direct effect revealed strong relationship (0.731) between the two traits.

The coefficient of determination and relative importance using path analysis for sugar yield and its related factors are shown in Table (3).

The results revealed that the greatest parts of sugar yield variability were explained by the direct effect of number of millable stalks $/ \mathrm{m}^{2}$ (18.65), sucrose \% (11.01) and stalk weight (10.77). The great contribution of these traits on sugar yield supported their importance as selection criteria in sugarcane breeding program. 
Table (3): The coefficient of determination (CD) and relative importance (RI \%) of sugar yield components in sugarcane.

\begin{tabular}{|c|c|c|c|}
\hline \multirow{2}{*}{\multicolumn{2}{|c|}{ Characters }} & \multicolumn{2}{|c|}{ Sugar yield (SY) } \\
\hline & & CD & RI \% \\
\hline \multicolumn{4}{|c|}{ Direct effects } \\
\hline \multicolumn{2}{|c|}{ Stalk weight (SW) } & 0.534 & $\underline{10.766}$ \\
\hline \multicolumn{2}{|c|}{ Stalk length (SL) } & 0.030 & 0.605 \\
\hline \multicolumn{2}{|c|}{ Stalk diameter (SD) } & 0.005 & 0.101 \\
\hline \multicolumn{2}{|c|}{ No. internodes/stalk (NI) } & 0.002 & 0.040 \\
\hline \multicolumn{2}{|c|}{ No. millable stalks $/ \mathrm{m}^{2}$ (NMS) } & 0.925 & 18.649 \\
\hline \multicolumn{2}{|c|}{ Total soluble solids (TSS \%) } & 0.028 & 0.565 \\
\hline \multicolumn{2}{|c|}{ Sucrose (S \%) } & 0.546 & $\underline{11.008}$ \\
\hline \multicolumn{2}{|c|}{ Reducing sugar (RS \%) } & 0.026 & 0.524 \\
\hline \multicolumn{4}{|c|}{ Indirect effects } \\
\hline \multirow{7}{*}{ SW via } & SL & 0.119 & 2.399 \\
\hline & SD & 0.09 & 1.815 \\
\hline & NI & -0.0116 & 0.234 \\
\hline & NMS & -1.129 & $\underline{22.762}$ \\
\hline & TSS \% & 0.014 & $\overline{0.282}$ \\
\hline & $\mathrm{S} \%$ & -0.014 & 0.282 \\
\hline & $\mathbf{R S} \%$ & -0.0085 & 0.171 \\
\hline \multirow{6}{*}{ SL via } & SD & 0.009 & 0.181 \\
\hline & NI & -0.0103 & 0.208 \\
\hline & NMS & -0.202 & $\underline{4.073}$ \\
\hline & TSS \% & 0.025 & $\overline{0.504}$ \\
\hline & $\mathrm{S} \%$ & -0.104 & 2.097 \\
\hline & RS \% & -0.015 & 0.302 \\
\hline \multirow{5}{*}{ SD via } & NI & -0.0006 & 0.012 \\
\hline & NMS & -0.11 & 2.218 \\
\hline & TSS \% & 0.002 & 0.040 \\
\hline & $\mathrm{S} \%$ & -0.002 & 0.040 \\
\hline & RS \% & -0.003 & 0.060 \\
\hline \multirow{4}{*}{ NI via } & NMS & 0.035 & 0.706 \\
\hline & TSS \% & -0.003 & 0.060 \\
\hline & $\mathrm{S} \%$ & 0.021 & 0.423 \\
\hline & RS \% & 0.004 & 0.081 \\
\hline \multirow{3}{*}{ NMS via } & TSS \% & -0.087 & 1.754 \\
\hline & $\mathrm{S} \%$ & 0.355 & $\underline{7.157}$ \\
\hline & RS \% & 0.057 & $\overline{1.149}$ \\
\hline \multirow{2}{*}{ TSS \% via } & $\mathrm{S} \%$ & -0.221 & $\underline{4.456}$ \\
\hline & $\mathrm{RS} \%$ & 0.007 & $\overline{0.141}$ \\
\hline $\mathbf{S} \%$ via & RS \% & -0.059 & 1.190 \\
\hline \multicolumn{2}{|c|}{ Total (direct + indirect) } & 0.854 & 97.06 \\
\hline \multicolumn{2}{|c|}{$\begin{array}{c}\text { Residuals } \\
\end{array}$} & 0.146 & 2.94 \\
\hline & & 1.000 & 100 \\
\hline
\end{tabular}

Note:Bold and underline cells indicate the highest values of direct and indirect effects. 
great contribution of these traits on sugar yield supported their importance as selection criteria in sugarcane breeding program.

According to the relative importance of joint effect components, it appeared that the highest values were recorded for the indirect effect of stalk weight on sugar yield through its association with the number of millable stalks $/ \mathrm{m}^{2}$ (22.76) followed by the joint effect of the number of millable stalks $/ \mathrm{m}^{2}$ via sucrose $\%$ (7.16) followed by the total soluble solids \% via sucrose \% (4.46) and stalk length through number of millable stalks $/ \mathrm{m}^{2}$ (4.07). Trivial values of relative importance were obtained by the other direct and indirect effects. Totally, the studied traits accounted for $97.06 \%$ of the sugar yield variation. The current results are in parallel line with those obtained by Hooda et al.(1990), Kang et al .(1983, 1989 and 1991), Choudhary and Singh (1994) and Tyagi and Lai (2007).

Although the path analysis provides a clear picture of the pattern of association, but it can not construct a prediction equation for sugar yield using its components. Considering this point of view, the multiple linear regression analysis may usefully play this role.

\subsection{Multiple linear regression analysis}

Data in Table (4) show the regression coefficients and their significance for some agronomic and chemical traits in predicting sugar yield using full model regression. The prediction equation was formulated as follows:

$\mathrm{SY}=-13.75+3.44(\mathrm{SW})-0.004(\mathrm{SL})+0.154$

$(\mathrm{SD})+0.032(\mathrm{NI})+0.477(\mathrm{NMS})-0.187(\mathrm{TSS}$ $\%)+0.777(\mathrm{~S} \%)+1.93(\mathrm{RS} \%)$.

In addition to the highly significance of the used model $(\mathrm{P}<0.01)$, it successfully accounted for $85.3 \%$ of the total variation of sugar yield expressed as $\mathrm{R}^{2}$. The residuals content $(14.7 \%)$ may be attributed to unknown variation (random errors), human errors during measuring the studied traits and/or some other traits that were not in account under the present investigation. Furthermore, the obtained results reported that the stalk weight, number of millable stalks $/ \mathrm{m}^{2}$, sucrose $\%$ and reducing sugar $\%$ significantly contributed towards sugar yield while the other four traits did not.l

On the other hand, the positive sign of the partial regression coefficient for the character of reducing sugar $\left(1.93^{*}\right)$ is a questionable point. But this confusion would vanish if we cnsidered the fact that the sugar yield is a function of the sucrose $\%$ and other components as follows:

Sugar yield $=$

Cane yield (ton/fed) x Sugar recovery $\%$.

Sugar recovery $\%=$

\{Sucrose \% - 0.4 (Brix \% - Sucrose \%) \} x 0.73

So, the positive relationship between reducing Sugar \% and cane yield (data not tabulated) may mask the logic negative association $(-0.25)$ between the reducing sugar \%

Table (4): Multiple linear regression model to explain sugar yield variation using some its related charactes.

\begin{tabular}{|c|c|c|c|c|}
\hline Characters Reg. Parameters & $\begin{array}{l}\text { Regression } \\
\text { coefficient } \\
\text { (b) }\end{array}$ & $\begin{array}{c}\text { Standard } \\
\text { Error (SE) }\end{array}$ & $\begin{array}{l}\text { Probability } \\
\text { level (P-value) }\end{array}$ & $\begin{array}{c}\text { Variance } \\
\text { Inflation } \\
\text { Factor (VIF) } \\
\end{array}$ \\
\hline Stalk weight (SW) & $3.44 * *$ & 0.68 & 000 & 6.41 \\
\hline Stalk length (SL) & -0.004 & 0.002 & 0.09 & 3.06 \\
\hline Stalk diameter (SD) & 0.154 & 0.318 & 0.63 & 6.45 \\
\hline No. internodes/stalk (NI) & 0.032 & 0.068 & 0.64 & 2.61 \\
\hline No. millable stalks/m² (NMS) & $0.477 * *$ & 0.066 & 000 & 5.40 \\
\hline Total soluble solids (TSS \%) & -0.187 & 0.161 & 0.25 & 6.40 \\
\hline Sucrose (S \%) & $0.777 * *$ & 0.163 & 000 & 7.30 \\
\hline Reducing sugar (RS \%) & $1.93 *$ & 0.90 & 0.037 & 1.70 \\
\hline $\begin{array}{l}\text { Intercept } \\
\text { Model sig. } \\
\mathbf{R}^{2} \\
\text { Adjusted } \mathbf{R}^{2}\end{array}$ & $\begin{array}{c}-13.75 \\
000 \\
85.3 \\
82.7\end{array}$ & & & \\
\hline
\end{tabular}


and sucrose $\%$ as stated in Table (1) (Kang et al.,1991).

Concerning the multicollinearity, the values of Variance Inflation Factor (VIF) for all the studied traits were less than 10 indicating trivial influence of multicollinearity problem. The present results ensured the goodness of fit for the proposed model of regression.

\subsection{Stepwise linear regression analysis}

This method was used to determine the more effective traits that mostly explained the variation of sugar yield. Table (5) showed the partial regression coefficients as well as their significance for the accepted limiting three variables that significantly contributing to variation of sugar yield. These variables were stalk weight, number of millable stalks $/ \mathrm{m}^{2}$ and sucrose \%. According to the results, $82.7 \%$ (expressed as $\mathrm{R}^{2}$ ) of the total variation in sugar yield could be attributed to these aforementioned three traits. The other five traits were not include in the model due to their very low relative contribution $\left(\mathrm{R}^{2}=2.6\right)$.

The prediction equation for sugar yield formula was as follows:

$\mathrm{SY}=$

$-13.65+4.213(\mathrm{SW})+0.5(\mathrm{NMS})+0.51(\mathrm{~S} \%)$.

On the other hand, the validity of the proposed model was established where the values of Variance Inflation Factor (VIF) for the accepted variables were less than 10 indicating no effect of multicollinearity.

As mentioned before, the stalk weight, number of millable stalks $/ \mathrm{m}^{2}$ and sucrose $\%$ were the most important variables according to stepwise analysis. Therefore, these three traits have to be ranked the first in any breeding program for improving sugar yield in sugarcane. The current results of full model regression and stepwise multiple linear regression were in harmony with those obtained by El-Shafai and Ismail (2006) and Iiyas and Khan (2010).

\subsection{Factor analysis}

The factor analysis technique divided the eight sugar yield components into three independent groups or factors which explained $85.31 \%$ of the total variability in the dependence structure. The factors were constructed by applying the principal component approach to establish the dependent relationship between sugar yield attributes in sugarcane. Factor loadings that greater than 0.5 were considered important. A summary of the composition of variables of the three extracted factors with loading are given in Table (6).

Factor I included three variables which accounted for $34.89 \%$ of the total variability. The three variables were stalk weight, stalk diameter and, the number of millable stalks $/ \mathrm{m}^{2}$. The sign of the loading values indicates the direction of the relationship between the factor and its related traits. So, the negative sign of the number of millable stalks $/ \mathrm{m}^{2}$ indicate to their negative correlation coefficients with each of the other two variables in factor I (Table 1). The three variables had high communality with factor I. Therefore, this factor may be called cane yield factor.

Factor II was made up of the total soluble solids \% and sucrose \%. Because factor II concerned with sugar content, it was called sugar factor. It accounted for $28.17 \%$ of the total variability in the dependence structure. In factor II, both variables had a high loading values in the factor.

Table (5): Regression parameters of the accepted variables according to stepwise multiple linear regression.

\begin{tabular}{|l||c|c|c|c|}
\hline Characters & $\begin{array}{c}\text { Regression } \\
\text { coefficient } \\
\text { (b) }\end{array}$ & $\begin{array}{c}\text { Standard Error } \\
\text { (SE) }\end{array}$ & $\begin{array}{c}\text { Probability } \\
\text { level (P-value) }\end{array}$ & $\begin{array}{c}\text { Variance } \\
\text { Inflation } \\
\text { Factor (VIF) }\end{array}$ \\
\hline Stalk weight (SW) & $4.213^{* *}$ & 0.49 & 000 & 3.15 \\
Number of millable stalks/m ${ }^{2}$ & $0.5 * *$ & 0.05 & 000 & 3.36 \\
Sucrose (\%) & $0.51 * *$ & 0.07 & 000 & 1.19 \\
\hline Intercept & -13.65 & & \\
Model sig. & 000 & & \\
$\mathbf{R}^{2}$ & 82.7 & & \\
Adjusted R $^{2}$ & 81.7 & & \\
$\mathbf{R}^{2}$ of eliminated traits & 2.6 &
\end{tabular}


Table (6): Summary of the factor loadings for the eight traits of sugarcane.

\begin{tabular}{|c|c|c|c|c|c|}
\hline Variables & Loading & Communality & Eigen values & $\begin{array}{c}\% \text { of } \\
\text { variance }\end{array}$ & $\begin{array}{c}\text { Suggested } \\
\text { factor name }\end{array}$ \\
\hline Factor I & & & \multirow{5}{*}{2.791} & \multirow{5}{*}{34.89} & \multirow{5}{*}{$\begin{array}{l}\text { Cane yield } \\
\text { factor }\end{array}$} \\
\hline Stalk weight & 0.96 & 0.925 & & & \\
\hline Stalk diameter & 0.956 & 0.917 & & & \\
\hline No. millable stacks $/ \mathrm{m}^{2}$ & -0.87 & 0.893 & & & \\
\hline Factor II & & & & & \\
\hline Total soluble solids $\%$ & 0.927 & 0.867 & \multirow{2}{*}{2.253} & \multirow{2}{*}{28.17} & \multirow{2}{*}{$\begin{array}{l}\text { Sugar } \\
\text { factor }\end{array}$} \\
\hline Sucrose $\%$ & 0.967 & 0.939 & & & \\
\hline Factor III & & & \multirow{4}{*}{1.78} & \multirow{4}{*}{22.25} & \multirow{4}{*}{$\begin{array}{l}\text { Growth } \\
\text { factor }\end{array}$} \\
\hline Stalk length & 0.655 & 0.796 & & & \\
\hline No. internodes/stalk & 0.813 & 0.765 & & & \\
\hline Reducing sugar $\%$ & 0.766 & 0.722 & & & \\
\hline Cumulative variance & \multicolumn{5}{|c|}{85.31} \\
\hline
\end{tabular}

Factor III was responsible for $22.25 \%$ of the total variability in the dependence structure. It included three characters namely: stalk length, number of internodes/stalk and reducing sugar $\%$. It contains the variables usually regarded as a growth factor. These results are in agreement with El-Geddawi et al. (1992). The use of factor analysis by plant breeders has the potential of increasing the comprehension of the casual relationship of variables and can help to determine the nature and sequence of traits to be selected in a breeding program.

Finally, it could be recommended from the previous results that, the important traits overall statistical procedures of analysis were the number of millable stalks $/ \mathrm{m}^{2}$, stalk weight and sucrose $\%$. These traits will enable the breeders or agronomists to realize high income of sugar yield in sugarcane.

\section{REFERENCES}

Ahmed A. O. , Obeid A. and Dafallah B. (2010). The influence of characters association on behavior of sugarcane genotypes (Saccharum spp.) for cane yield and juice quality. World J. Agric. Sci., 6(2): 207-211.

Cattell R. B. (1965). Factor analysis on introduction to essentials. The purpose and underlying models. Biometrics, 21: 190-215.

Choudhary A. K. and Singh J. R. P. (1994). Correlation and path coefficient studies in early maturing clones of sugarcane
( Saccharum spp. Complex). Cooperative Sugar, 25: 305-307.

Dewey D. R. and Lu K. H. (1959). A correlation and path coefficient analysis of components of crested wheat grass seed production. Agron. J., 51: 515-518.

Draper N. R. and Smith H. (1981). Applied Regression Analysis. John Wiley \& Sons Inc., New York.

El-Geddawi I. H., Nasr S. M. and Abo-Douh A. M. (1992). Factor analysis of yield components of sugar cane. Pak. Sugar J. VI(3): 11-14.

El-Shafai A. M. and Ismail A. M. A. (2006). Effect of row spacing on yield and quality of some promising sugarcane varieties. Egyp. J. Appl. Sci., 21(11): 32-46.

Hair J. F., Anderson J. R., Tatham R. L. and Black W. C. (1992). Multivariate Data Analysis. Macmillan Pub. Comp., A division of Macmillan, Inc.

Hooda M. S., Singh S. and Chaudhary B. S. (1990). Path analysis of commercial cane sugar in sugarcane. Research and Development Reporter. 7: 115-117.

Iiyas M. K. and Khan F. A. (2010). Determining sucrose recovery in Saccharum officinarum L. using regression and correlation analyses. African J. Biotech. 9(20): 2985-2988.

Kaiser H. F. (1958). The varimax criterion for analytic notation in factor analysis. Psychometrica, 23: 187. 
Kang M. S. (1994). Applied quantitative genetics. Kang Publ. Baton Rouge, LA, USA.

Kang M. S., Miller J. D. and Tai P. (1983). Genetic and phenotypic path analysis and heritability in sugarcane. Crop Sci., 23: 643647.

Kang M. S., Sosa O. and Miller J. D. (1989). Path analysis for percent fibre, and cane and sugar yield in sugarcane. Crop Sci., 29: 1481-1483.

Kang M. S., Tai P. and Miller J. D. (1991)
.Genetic and phenotypic path analyses in sugarcane: artificially created relationships. Crop Sci., 31: 1684-1686.

Steel R. G. D. and Torrie J. H. (1980). Principles and procedures of statistics. A Biometrical Approach, $2^{\text {nd }}$ Ed., Iowa State Univ., press Ames, Iowa, USA.

Tyagi A. P. and Lai P. (2007). Correlation and path coefficient analysis in sugarcane. The South Pacific J. of Natural Science, 1: 1-10.

$$
\begin{aligned}
& \text { تحليل المتغيرات المتعددة لمكونات محصول السكر فى قصب السكر } \\
& \text { حسين محم السيد ـ هيام سيد احمد فاتح*ـ وليد محمد فارس* } \\
& \text { معهد بحوث المحاصيل السكرية _*المعمل المركزى لبحوث التصميم و التحليل الاحصائى ـ }
\end{aligned}
$$

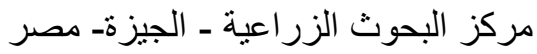

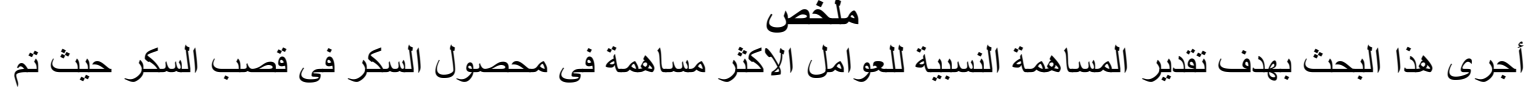

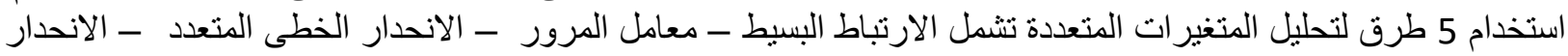

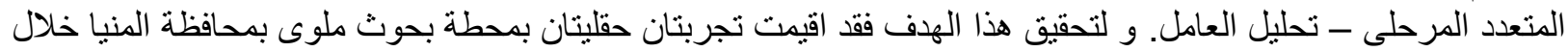

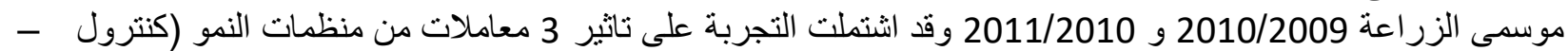

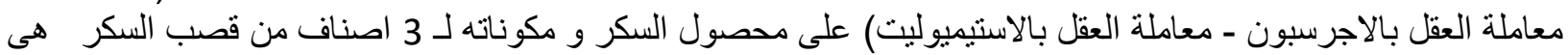

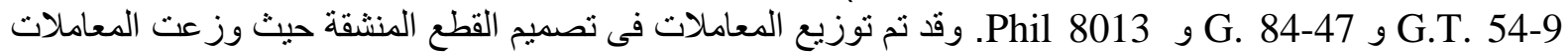

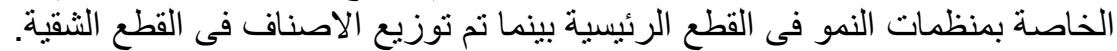

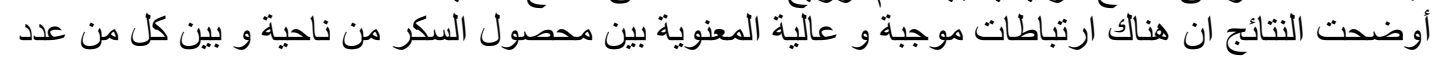

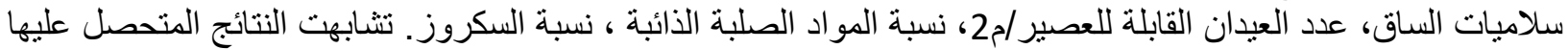

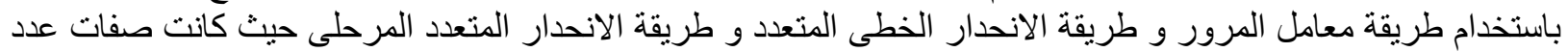

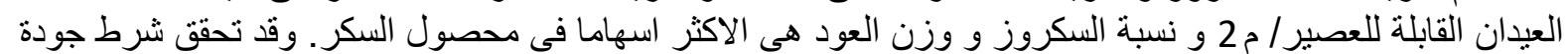

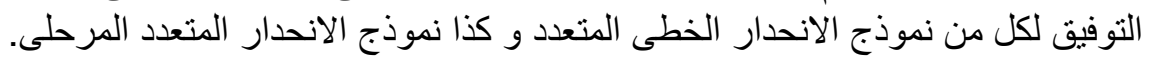

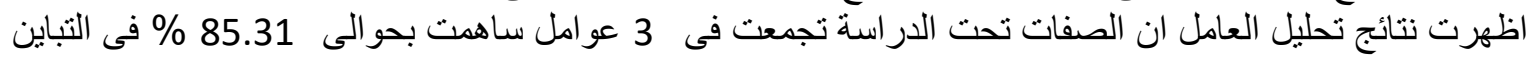

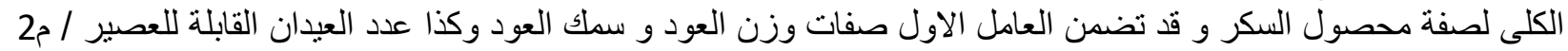
وقد ساهم هذا العامل بحو الى 34.89 \% من التباين الكلى لمحصول السكر . اما العامل الثانى فقد ساهم بحو الى 28.17 \% 28.

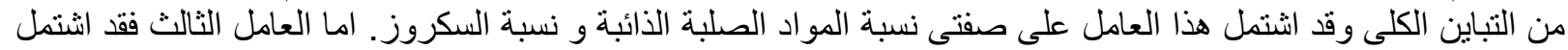

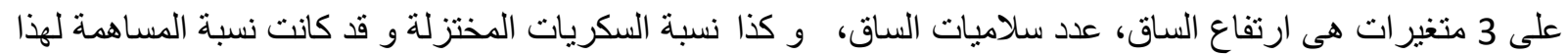

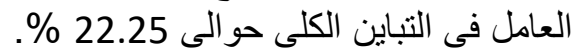

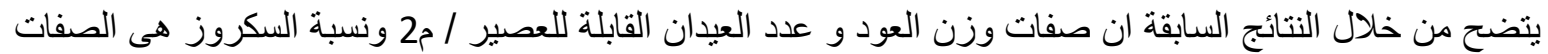
الاكثر اسهاما فى محصول السكر و يجب على المربى الاستفادة منها فى بر امج التربية لتحسين و ولئيل زيادة انتاجية محصول

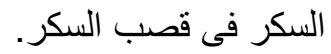
المجلة العلمية لكلية الزراعة ـ جامعة القاهرة ـ المجلد (62)(لعدد الرابع (أكتوبر2011):409-417. 